\title{
Pengaruh Kualitas Pelayanan dan Periklanan terhadap Keputusan Nasabah dalam Menabung pada Bank Syariah \\ (Studi Kasus pada BTN Syariah Surakarta)
}

\author{
Helmi Haris dan Nur Said Irham T \\ Institut Agama Islam Negeri Surakarta \\ helmi.solo@gmail.com
}

\begin{abstract}
:
This research aims to analyze the influence of service quality and advertising partially and simultaneously against the costumer decisions in saving money at Bank Tabungan Negara (BTN) Syariah Surakarta. The population in this research are the total number of clients who save in Bank Tabungan Negara (BTN) Sharia Surakarta and using the Accidental Sampling as the method in sampling (numbers of sample are 98 respondent). The analysis tool that used in this research is "multiple linear regression", which previously tested the validity and realibility as well as the classic assumption test. Based on the partial testing, both of service quality and advertising have significant influence positively with the level of $\square=5 \%(0,05)$. The simultaneous test showed that the influence of service quality and advertising is significant with calculate $\mathrm{F}$ value 29.629 and the value of $\mathrm{F}$ table is 3.09.
\end{abstract}

Keywords: service quality, costumer, sharia, bank

\section{Pendahuluan}

Persaingan dunia bisnis perbankan di Indonesia saat ini semakin gencar yang salah satunya ditandai dengan banyaknya jumlah bank yang beroperasi. Lebih spesifik menunjuk pada perbankan syariah, saat ini semakin banyak bank-bank konvensional yang membuka unit usaha syariah -baik dengan membuka baru atau mengkonversi cabangnya- ataupun melakukan spin off menjadi BUS baru.

Persaingan sektor perbankan syariah juga sangat terasa di Kota Surakarta. Pertumbuhan bisnis perbankan syariah di kota ini lebih pesat dibanding- 
kan dengan perbankan konvensional. Tahun 2010, pertumbuhan aset perbankan syariah di Kota Surakarta lebih dari 40 persen, sedangkan bank konvensional sekitar 20 persen. Data BI menunjukkan bahwa sampai dengan bulan September 2011, di Surakarta tercatat ada 14 bank syariah yang beroperasi, baik dalam bentuk BPRS, UUS maupun BUS (Statistik BI, 2011). Salah satu bank syariah di Surakarta yang mempunyai nasabah cukup besar adalah Bank Tabungan Negara (BTN) Syariah Surakarta yang merupakan Strategic Bussiness Unit (SBU) dari Bank BTN.

Dengan besarnya masyarakat floating di Indonesia, sebuah bank dituntut untuk dapat memberikan profit bagi para nasabahnya. Salah satu yang bisa ditempuh adalah dengan melakukan berbagai strategi marketing mix untuk menghimpun dana masyarakat serta menciptakan inovasi produk yang lebih variatif (Baria'ah, 2009). Hal lain yang juga tidak kalah penting untuk meningkatkan market share sebuah bank adalah peningkatan kualitas pelayanan dan periklanan (Swastha, 2003).

Pelayanan dan periklanan merupakan dua hal yang bisa memberikan daya saing sebuah bank di mata masyarakat. Dalam aspek pelayanan, masyarakat tentunya akan memilih bank yang aman dengan prosedur yang tidak terlalu rumit dan layanan yang memuaskan, seperti layanan yang diberikan oleh para pegawai yang murah senyum, ramah, bersahabat, sopan, sigap atau tanggap, handal, profesional, responsif dan mampu melayani dengan cepat. Jelas betapa pentingnya bank memusatkan perhatiannya terutama pada usaha mencegah berpindahnya nasabah ke bank lainnya, sehingga dapat dikatakan bahwa kualitas layanan mempunyai pengaruh yang cukup besar dalam menentukan minat nasabah untuk menggunakan jasa bank. Sedangkan dalam aspek periklanan, sebuah bank yang memasang iklan (dalam bentuk apapun) akan dapat dilihat oleh masyarakat sehingga masyarakat akan mempertimbangkan untuk menggunakan jasa bank yang bersangkutan.

Berdasarkan pada kondisi yang telah dipaparkan, penelitian ini bermaksud untuk melihat bagaimanakah pengaruh kualitas pelayanan dan periklanan terhadap keputusan nasabah dalam menabung pada BTN Syariah Surakarta. 


\section{Rumusan Masalah}

Berdasarkan latar belakang masalah yang dikemukakan di atas, peneliti merumuskan permasalahan yang dikaji dalam penelitian ini sebagai berikut:

a. Apakah kualitas pelayanan mempunyai pengaruh terhadap keputusan nasabah dalam menabung pada Bank Tabungan Negara Syariah Surakarta?

b. Apakah periklanan mempunyai pengaruh terhadap keputusan nasabah dalam menabung pada Bank Tabungan Negara Syariah Surakarta?

\section{Landasan Teori}

\section{Pelayanan}

Parasuraman mengajukan 5 faktor untuk menilai kualitas pelayanan, yaitu tangible (bukti fisik), reliability (keandalan), responsiveness (daya tanggap), assurance (jaminan), emphaty (empati) (Tjiptono, 2001: 70). Dimensi bukti fisik atau tangible muncul karena dalam industri jasa, konsumen dihadapkan pada janji-janji yang ditawarkan (intangible) dari penyedia jasa (Kotler, 2001: 602).

Pentingnya dimensi tangible ini akan menumbuhkan image penyedia jasa terutama bagi konsumen baru dalam mengevaluasi kualitas jasa. Penerapan untuk bank syariah sendiri yaitu dengan desain ruangan yang menggambarkan image bank syari'ah, misal terdapat mushola yang cukup luas, ataupun pelayanan yang terbuka terhadap nasabah tanpa adanya pelakuan yang bersifat diskriminatif. Selain itu juga pelayanan dalam bentuk produk yang bisa membuat nasabah tertarik dan merasa aman dan nyaman untuk menyimpan ataupun mengajukan pembiayaan. Sebab nasabah pasti akan berpikir dalam mengajukan pembiayaan apabila nanti sekirannya margin yang diberikan nasabah terlalu besar (memberatkan nasabah). Reliability atau keandalan merupakan kemampuan perusahaan untuk melaksanakan jasa sesuai dengan apa yang telah dijanjikan secara tepat waktu (Tjiptono, 2001: 70).

Daya tanggap atau responsiveness dapat menumbuhkan persepsi yang positif terhadap kualitas jasa yang diberikan. Termasuk didalamnya 
jika terjadi kegagalan atau keterlambatan dalam penyampaian jasa, pihak penyedia jasa berusaha memperbaiki atau meminimalkan kerugian konsumen dengan segera. Assurance atau jaminan merupakan pengetahuan dan perilaku employer untuk membangun kepercayaan dan keyakinan pada diri konsumen dalam menggunakan jasa yang ditawarkan (Umar, 2003: 8). Emphaty merupakan kemampuan perusahaan yang dilakukan langsung oleh karyawan untuk memberikan perhatian kepada konsumen secara individu, termasuk juga kepekaan akan kebutuhan konsumen. Perusahaan jasa juga perlu memberikan perhatian secara individual atau faktor emphaty, agar layanan yang diberikan dapat dikatakan berkualitas baik dan memuaskan pengguna jasa. Kualitas pelayanan merupakan tingkatan kondisi baik buruknya sajian yang diberikan perusahaan jasa dalam rangka memuaskan konsumen dengan cara memberikan atau menyampaikan jasa yang melebihi harapan konsumen (Tjiptono, 2001: 58). Jadi penilaian konsumen terhadap kualitas pelayanan merupakan refleksi persepsi evaluatif terhadap pelayanan yang diterimanya pada waktu tertentu.

Parasuraman menggunakan 5 dimensi untuk mengevaluasi kualitas jasa pelanggan, yaitu: Tangibles, Reliability, Responsiveness, Assurance, Emphaty. Dimensi Tangible melihat bukti nyata dari kepedulian dan perhatian yang diberikan oleh penyedia jasa kepada konsumen (Umar 2003: 8-9). Reliability merupakan kemampuan perusahaan untuk melaksanakan jasa sesuai dengan apa yang telah dijanjikan tepat waktu. Responsiveness merupakan kemampuan perusahaan yang dilakukan oleh langsung karyawan untuk memberikan pelayanan dengan cepat dan tanggap. Assurance merupakan pengetahuan dan perilaku karyawan untuk membangun kepercayaan dan keyakinan pada diri konsumen dalam mengkonsumsi jasa yang ditawarkan. Emphaty merupakan kemampuan perusahaan yang dilakukan langsung oleh karyawan untuk memberikan perhatian kepada konsumen secara individu, termasuk juga kepekaan akan kebutuhan konsumen.

\section{Periklanan}

Periklanan adalah semua bentuk penyajian non personal, informasi, promosi ide-ide, promosi barang atau jasa yang dilakukan oleh sponsor tertentu yang dibayar. Iklan dibuat menarik perhatian dan mudah diingat dengan 
tujuan untuk mempengaruhi orang agar membeli barang dan jasa tertentu (Kotler, 2001: 245).

Istilah periklanan berbeda dengan iklan karena iklan adalah beritanya itu sendiri, sedangkan periklanan adalah prosesnya, yaitu suatu program kegiatan untuk mempersiapkan berita tersebut dan menyebarluaskan kepada pasar. Iklan dapat dilakukan pada media televisi, surat kabar, radio, majalah, penyebaran brosur, plakat maupun pemasangan papan reklame. Masingmasing pemilihan media tersebut memiliki kelemahan dan kelebihan.

Terdapat lima sifat iklan yang berhubungan erat dengan ketidakberwujudan (intangibility) dari iklan (Wahjono, 2010). Sifat-sifat itu mencakup keberadaannya yang abstrak (abstractness), penyajian publik (public presentation), kemampuan meresap (diffuseness), ekspresi yang diperkuat (strengthened ecpression) dan tidak mengenai orang tertentu (impersonality).

\section{Minat Menabung}

Minat untuk menabung merupakan bagian atau salah satu elemen penting dari perilaku nasabah disamping kegiatan fisik yang melibatkan nasabah dalam menilai, mendapatkan dan mempergunakan barang-barang serta jasa ekonomis. Secara umum, perilaku pengambilan keputusan untuk membeli atau mempergunakan jasa tertentu dipengaruhi oleh beberapa faktor, yaitu: harga, service yang ditawarkan, lokasi, kemampuan tenaga penjual, periklanan (Kotler, 2001: 206).

Keputusan untuk menabung di suatu lembaga perbankan merupakan suatu pemilihan tindakan dari dua atau lebih pilihan alternatif. Dengan kata lain, orang yang mengambil keputusan harus mempunyai satu pilihan dari beberapa alternatif yang ada (Ristiyanti, 2005: 226).

\section{Hipotesis}

Atas dasar pokok masalah dan tujuan pembahasan dalam skripsi ini, maka hipotesa yang dikemukakan adalah:

H1 : Kualitas pelayanan berpengaruh terhadap keputusan nasabah menabung.

H2 : Periklanan berpengaruh terhadap keputusan nasabah menabung. 
H3 : Kualitas Pelayanan dan Periklanan secara simultan berpengaruh terhadap Keputusan Menabung

\section{Metodologi Penelitian}

\section{Populasi dan Sampel}

Populasi penelitian ini adalah jumlah keseluruhan para nasabah yang menabung di Bank Tabungan Negara Syari'ah Surakarta sampai tahun 2011 sebesar 4000 nasabah. Dari populasi sejumlah tersebut, berdasarkan pada rumusan Slovin maka jumlah minimal sampel yang diambil sebesar 98 nasabah yang kemudian diambil dengan metode purposive sampling.

\section{Data dan Sumber Data}

Penelitian ini menggunakan data primer yang diperoleh dengan menyusun kuesioner yang kemudian dibagikan kepada nasabah selaku responden penelitian untuk mengetahui bagaimana tanggapan nasabah tentang kualitas pelayanan dan periklanan yang disediakan oleh BTN Syariah Surakarta.

\section{Tehnik Analisis Data}

Penelitian ini menggunakan metode kuantitatif dengan runutan sebagai berikut :

A. Uji Asumsi Klasik

Untuk mendapatkan model regresi yang baik dan terhindar dari penyimpangan data perlu dilakukan uji multikolonieritas, heteroskedassitas, autokorelasi dan normalitas (Ghozali, 2005: 57-74).

1) Uji Multikoleniaritas

Uji multikoleniaritas ini dilakukan dengan melihat nilai variance inflation factor (VIF) uji ini bertujuan untuk menguji apakah dalam model regresi ditemukan adanya korelasi antar variabel bebas. Pada model regresi yang baik, sebaiknya tidak terjadi korelasi diantara variabel bebas. Untuk mendeteksi ada tidaknya dengan melihat (1) nilai tolerance dan lawannya, (2) variance inflation factor. Kedua 
ukuran ini menujukkan setap variabel bebas manakah yang dijelaskan oleh variabel bebas lainnya. Tolerance mengukur variabilitas bebas yang terpilih yang tidak dapat dijelaskan oleh variabel bebas lainnya. Jadi nilai tolerance yang rendah sama dengan nilai VIF (karena VIF $=1 /$ tolerance) dan menunjukkan adanya kolenieritas yang tinggi. Nilai cut off yang dipakai oleh nilai tolerance 0,10 atau sama dengan nilai VIF di atas 10. Apabila terdapat variabel bebas yang memiliki nilai tolerance lebih dari 0,10 nilai VIF kurang dari 10, maka dapat disimpulkan bahwa tidak ada multikoleniaritas antar variabel bebas dalam model regresi (Ghozali, 2005: 57).

2) Uji Heteroskedastisitas

Uji heteroskedastisitas bertujuan menguji apakah dalam model regresi terjadi ketidaksamaan variance dari residual data yang ada. Model regresi yang baik adalah yang tidak mengalami gejala heteroskedastisitas. Cara yang digunakan dalam pengujian ini adalah dengan analisa grafik plot antara nilai prediksi variabel terikat (ZPRED) dengan residualnya (SRESID). Deteksi ada tidaknya heteroskedastisitas dapat dilakukan dengan melihat ada tidaknya pola tertentu pada grafik scatter plot antara SRESID dan ZPRED dimana sumbu Y adalah Y yang telah diprediksi, dan sumbu $X$ adalah residual (Yprediksi Ysesungguhnya) yang telah di Studentized. Dasar analisis:

Jika ada pola tertentu, serta titik-titik yang ada membentuk pola tertentu yang teratur (bergelombang, melebar kemudian, menyempit), maka mengindikasikan telah terjadi heteroskedastisitas.

Jika tidak ada pula yang jelas, serta titik-titik menyebar di atas dan dibawah angka $\mathrm{O}$ pada sumbu $\mathrm{Y}$, maka tidak terjadi heteroskedastisitas.

3) Uji Normalitas

Uji normalitas bertujuan untuk menguji apakah dalam modal regresi, variabel terikat dan variabel bebas keduanya mempunyai distribusi normal atau tidak. Model regresi yang baik memiliki distribusi data normal atau mendekati normal. Salah satu cara termudah untuk melihat normalitas adalah dengan melihat histrogram yang membandingkan antara data observasi dengan distribusi yang mendekati distribusi 
normal. Model regresi yang baik adalah memiliki distribusi data normal atau mendekati normal. Artinya kriteria berdistribusi normal apabila tampilan grafiknya menunjukkan pola penyebaran disekitar garis diagonal dan mengikuti arah garis diagonal (Ghozali, 2005: 74).

B. Analisis regresi linier berganda

Analisis regresi linier berganda adalah suatu alat analisis peramalan nilai pengaruh dua variabel bebas atau lebih terhadap variabel terikat untuk membuktikan ada atau tidaknya hubungan fungsi atau hubungan kausal antara dua variabel bebas atau lebih dengan satu variabel terikat (Riduwan, 2004: 152). Teknik analisis regresi linier berganda pada penelitian ini menggunakan alat bantu program SPSS.

Rumus :

$\mathrm{v}=\mathrm{a}+\mathrm{b}_{1} \mathrm{x}_{1}+\mathrm{b}_{2} \mathrm{x}_{2}$

Dimana :

$\mathrm{v}=$ Keputusan Nasabah

$\mathrm{X}_{1}=$ Kualitas Pelayanan

$\mathrm{X}_{2}=$ Periklanan

$\mathrm{b}_{1}=$ Koefisien regresi variabel antara $\mathrm{x}_{1}$ dan $\mathrm{y}$

$\mathrm{b}_{2}=$ Koefisien regresi variabel antara $\mathrm{x}_{2}$ dan $\mathrm{y}$

$\mathrm{a}=$ konstanta

C. Uji Ketepatan Model

a. Koefisien Determinasi.

Menurut Ghozali (2005: 83) bahwa koefisien determinasi pada intinya mengukur seberapa jauh kemampuan model dalam menerangkan variasi variabel dependen. Nilai koefisien determinasi adalah antara nol dan satu. Nilai koefisien determinasi yang kecil berarti kemampuan variabel-variabel independent dalam menjelaskan variasi variabel dependen amat terbatas. Untuk menentukan nilai koefisien determinasi dinyatakan dengan nilai Adjusted R Square. Adapun rumus koefisien determinasi dalam penelitian ini:

$\mathrm{R}^{2}=(\mathrm{r})^{2} \times 100 \%$ 
dimana :

$\mathrm{R}^{2}=$ koefisien determinasi

$\mathrm{r}=$ koefisien korelasi

b. Uji F (Uji Simultan)

Uji $\mathrm{F}$ yaitu digunakan untuk mengetahui pengaruh kualitas pelayanan dan periklanan secara bersama-sama terhadap keputusan nasabah dalam menabung.

D. Pengujian Hipotesa

Uji t(Uji Parsial)

Uji t yaitu suatu uji untuk mengetahui pengaruh kualitas pelayanan dan periklanan terhadap keputusan nasabah dalam menabung secara parsial.

\section{Analisis dan Pembahasan}

\section{Identitas Responden}

Dari kuesioner yang telah diisi oleh responden didapat data identitas responden. Penyajian data mengenai identitas responden untuk memberikan gambaran tentang keadaan diri dari pada responden.

\section{Jenis Kelamin Responden}

Penyajian data responden berdasarkan jenis kelamin adalah sebagai berikut ini:

Tabel 4.1.1

Data Jenis Kelamin Responden

\begin{tabular}{|l|r|r|}
\hline & Frequency & Percent \\
\hline Laki-Laki & 50 & 51,0 \\
\hline Perempuan & 48 & 49,0 \\
\hline Total & 98 & 100,0 \\
\hline
\end{tabular}

Data Primer diolah, 2011

Berdasarkan tabel dapat diketahui bahwa responden terbanyak adalah laki-laki yaitu sebanyak 50 orang (51\%) dibanding perempuan yang hanya 48 orang $(49 \%)$. 


\section{Pekerjaan Responden}

Tabulasi pekerjaan responden dapat dilihat sebagai berikut:

Tabel 4.1.2

Pekerjaan Responden

\begin{tabular}{|l|r|r|}
\hline & Frequency & Percent \\
\hline Karyawan & 27 & 27,6 \\
\hline Mahasiswa & 2 & 2,0 \\
\hline PNS & 13 & 13,3 \\
\hline Polisi & 2 & 2,0 \\
\hline Wiraswasta & 54 & 55,1 \\
\hline Total & 98 & 100,0 \\
\hline
\end{tabular}

Data Primer diolah, 2011

Berdasarkan tabel dapat diketahui bahwa untuk pekerjaan responden yang terbanyak adalah Wiraswasta yaitu sebanyak 54 orang dengan prosentase $55,1 \%$, diikuti dengan Karyawan sebanyak 27 orang atau 27,6\%, lalu PNS sebanyak 13 orang dengan prosentase $13,3 \%$, dan yang terakhir dengan jumlah yang sedikit yaitu Mahasiswa dan Polisi sejumlah masing-masing dua orang dengan prosentase $2,0 \%$.

\section{Deskripsi Data Penelitian}

Berdasarkan hasil penelitian yang telah dilakukan terhadap 98 responden melalui penyebaran kuesioner. Untuk mendapatkan kecenderungan jawaban responden terhadap jawaban masing-masing variabel akan didasarkan pada rentang skor jawaban sebagaimana pada lampiran.

\section{a. Variabel Pelayanan}

Variabel pelayanan pada penelitian ini diukur melalui 10 buah pertanyaan meliputi lima dimensi yaitu, tangible (bukti fisik), reliability (keandalan), responsiveness (daya tanggap), assurance (jaminan), emphaty (empati) yang mempresentasikan indikator-indikator dari variabel tersebut. Hasil tanggapan terhadap pelayanan dapat dijelaskan pada tabel berikut: 
Tabel 4.2.1

Data Variabel Pelayanan

\begin{tabular}{|c|c|c|c|c|c|c|c|}
\hline No & $\begin{array}{c}\text { Item } \\
\text { pertanyaan }\end{array}$ & STS & TS & $\mathbf{N}$ & $\mathbf{S}$ & SS & Total \\
\hline \multirow[t]{2}{*}{1} & \multirow[t]{2}{*}{ X.1.1 } & 0 & 0 & 1 & 43 & 54 & 98 \\
\hline & & 0 & 0 & $1 \%$ & $43,9 \%$ & $55,1 \%$ & $100 \%$ \\
\hline \multirow[t]{2}{*}{2} & \multirow[t]{2}{*}{ X.1.2 } & 0 & 1 & 11 & 68 & 18 & 98 \\
\hline & & $0 \%$ & $1 \%$ & $11,2 \%$ & $69,4 \%$ & $18,4 \%$ & $100 \%$ \\
\hline \multirow[t]{2}{*}{3} & \multirow[t]{2}{*}{ X.1.3 } & 5 & 17 & 27 & 37 & 12 & 98 \\
\hline & & $5,1 \%$ & $17,3 \%$ & $27,6 \%$ & 37,85 & $12,2 \%$ & $100 \%$ \\
\hline \multirow[t]{2}{*}{4} & \multirow[t]{2}{*}{ X.1.4 } & 0 & 0 & 11 & 63 & 24 & 98 \\
\hline & & 0 & 0 & $11,2 \%$ & $64,3 \%$ & $24,5 \%$ & $100 \%$ \\
\hline \multirow[t]{2}{*}{5} & \multirow[t]{2}{*}{ X.1.5 } & 0 & 0 & 18 & 62 & 18 & 98 \\
\hline & & 0 & 0 & $18,4 \%$ & $63,3 \%$ & $18,4 \%$ & $100 \%$ \\
\hline \multirow[t]{2}{*}{6} & \multirow[t]{2}{*}{ X.1.6 } & 0 & 0 & 15 & 65 & 18 & 98 \\
\hline & & 0 & 0 & $15,3 \%$ & $66,3 \%$ & $18,4 \%$ & $100 \%$ \\
\hline \multirow[t]{2}{*}{7} & \multirow[t]{2}{*}{ X.1.7 } & 0 & 0 & 23 & 61 & 14 & 98 \\
\hline & & 0 & 0 & $23,5 \%$ & $62,2 \%$ & $14,3 \%$ & $100 \%$ \\
\hline \multirow[t]{2}{*}{8} & \multirow[t]{2}{*}{ X.1.8 } & 0 & 0 & 18 & 58 & 22 & 98 \\
\hline & & 0 & 0 & $18,4 \%$ & $59,2 \%$ & $22,4 \%$ & $100 \%$ \\
\hline \multirow[t]{2}{*}{9} & \multirow[t]{2}{*}{ X.1.9 } & 0 & 0 & 22 & 57 & 19 & 98 \\
\hline & & 0 & 0 & $22,4 \%$ & $58,2 \%$ & $19,4 \%$ & $100 \%$ \\
\hline \multirow[t]{2}{*}{10} & \multirow[t]{2}{*}{ X.1.10 } & 0 & 1 & 15 & 66 & 16 & 98 \\
\hline & & 0 & $1,0 \%$ & $15,3 \%$ & $67,3 \%$ & $16,3 \%$ & $100 \%$ \\
\hline & \multirow[t]{2}{*}{ Jumlah } & & & & & & 980 \\
\hline & & & & & & & $100 \%$ \\
\hline
\end{tabular}

Data Primer diolah, 2011

Berdasarkan tabel IV.5 dapat dilihat bahwa, sebanyak lima nasabah sangat tidak setuju apabila BTN Syariah mempunyai parkir yang luas, 17 nasbah tidak setuju apabila BTN Syariah mempunyai lahan parkir yang luas, 27 nasabah memilih netral apabila BTN Syariah mempunyai lahan parkir yang luas, sebanyak 68 nasabah setuju dengan tata letak ruangan BTN Syariah menarik dan 54 nasabah sangat setuju dengan karyawan BTN Syariah bersih, rapi dan berpakaian serasi. 


\section{b. Variabel Periklanan}

Variabel periklanan pada penelitian ini diukur melalui 5 buah pertanyaan yang mempresentasikan indikator-indikator dari variabel tersebut. Hasil tanggapan terhadap periklanan dapat dijelaskan pada tabel berikut:

Tabel 4.2.2

Data Variabel Periklanan

\begin{tabular}{|c|l|c|c|c|c|c|c|}
\hline No & $\begin{array}{c}\text { Item } \\
\text { pertanyaan }\end{array}$ & STS & TS & N & S & SS & Total \\
\hline 1 & X.2.1 & 0 & 3 & 30 & 49 & 16 & 98 \\
\cline { 3 - 8 } & & 0 & $3,1 \%$ & $30,6 \%$ & $50,0 \%$ & $16,3 \%$ & $100 \%$ \\
\hline 2 & \multirow{2}{*}{ X.2.2 } & 0 & 0 & 34 & 58 & 6 & 98 \\
\cline { 3 - 8 } & & 0 & 0 & $34,7 \%$ & $59,2 \%$ & $6,1 \%$ & $100 \%$ \\
\hline \multirow{2}{*}{3} & \multirow{2}{*}{ X.2.3 } & 0 & 0 & 28 & 63 & 7 & 98 \\
\cline { 3 - 8 } & & 0 & 0 & $28,6 \%$ & $64,3 \%$ & $7,1 \%$ & $100 \%$ \\
\hline \multirow{2}{*}{4} & \multirow{2}{*}{ X.2.4 } & 0 & 0 & 36 & 53 & 9 & 98 \\
\cline { 3 - 8 } & & 0 & 0 & $36,7 \%$ & $54,1 \%$ & $9,2 \%$ & $100 \%$ \\
\hline 5 & \multirow{2}{*}{ X.2.5 } & 0 & 1 & 33 & 55 & 9 & 98 \\
\cline { 3 - 8 } & & 0 & $1,0 \%$ & $33,7 \%$ & $56,1 \%$ & $9,2 \%$ & $100 \%$ \\
\hline \multirow{2}{*}{ Jumlah } & & & & & & 420 \\
\cline { 3 - 8 } & & & & & & $100 \%$ \\
\hline
\end{tabular}

Data Primer diolah, 2011

Berdasarkan tabel IV.6 dapat dilihat bahwa, sebanyak tiga nasabah tidak setuju dengan iklan produk BTN Syariah memberikan informasi yang jelas, sebanyak 36 nasabah netral dengan iklan produk BTN Syariah menarik, sebanyak 63 nasabah setuju dengan iklan produk BTN Syariah mudah diikuti, dan 16 orang sangat setuju dengan iklan produk BTN Syariah memberikan informasi yang jelas.

\section{c. Variabel Keputusan}

Variabel keputusan pada penelitian ini diukur melalui 5 buah pertanyaan yang mempresentasikan indikator-indikator dari variabel tersebut. Hasil tanggapan terhadap keputusan dapat dijelaskan pada tabel berikut: 
Tabel 4.2.3

Data Variabel Keputusan

\begin{tabular}{|c|c|c|c|c|c|c|c|}
\hline No & $\begin{array}{c}\text { Item } \\
\text { pertanyaan }\end{array}$ & STS & TS & $\mathbf{N}$ & $\mathbf{S}$ & SS & Total \\
\hline \multirow[t]{2}{*}{1} & \multirow[t]{2}{*}{ Y.1 } & 0 & 1 & 35 & 49 & 13 & 98 \\
\hline & & 0 & $1,0 \%$ & $35,7 \%$ & $50,0 \%$ & $13,3 \%$ & $100 \%$ \\
\hline \multirow[t]{2}{*}{2} & \multirow[t]{2}{*}{ Y.2 } & 0 & 1 & 46 & 43 & 8 & 98 \\
\hline & & 0 & $1,0 \%$ & $46,9 \%$ & $43,9 \%$ & $8,2 \%$ & $100 \%$ \\
\hline \multirow[t]{2}{*}{3} & \multirow[t]{2}{*}{ Y.3 } & 0 & 2 & 37 & 44 & 15 & 98 \\
\hline & & 0 & $2,0 \%$ & $37,8 \%$ & $44,9 \%$ & $15,3 \%$ & $100 \%$ \\
\hline \multirow[t]{2}{*}{4} & \multirow[t]{2}{*}{ Y.4 } & 0 & 0 & 48 & 47 & 3 & 98 \\
\hline & & 0 & 0 & $49,0 \%$ & $48,0 \%$ & $3,0 \%$ & $100 \%$ \\
\hline \multirow[t]{2}{*}{5} & \multirow[t]{2}{*}{ Y.5 } & 0 & 0 & 37 & 55 & 6 & 98 \\
\hline & & 0 & 0 & $37,8 \%$ & $56,1 \%$ & $6,1 \%$ & $100 \%$ \\
\hline & \multirow[t]{2}{*}{ Jumlah } & & & & & & 420 \\
\hline & & & & & & & $100 \%$ \\
\hline
\end{tabular}

Data Primer diolah, 2011

Berdasarkan tabel IV.6 dapat dilihat bahwa, dua nasabah tidak setuju apabila standar dan harapan saya (nasabah) terhadap produk yang dipilih sangat tinggi, sebanyak 48 nasabah memilih netral dengan semua informasi yang saya (nasabah) peroleh pada produk yang berbeda-beda membuatnya bingung, 55 nasabah setuju biasanya membandingkan beberapa produk BTN Syariah dengan produk Bank Syariah lainnya, dan 15 nasabah sangat standar dan harapannya terhadap produk yang dipilihnya sangat tinggi.

\section{Pengujian Kualitas Data}

\section{a. Uji Validitas}

Uji validitas digunakan untuk mengukur sejauh mana kuesioner dapat mengukur objek yang akan diukur. Tehnik yang digunakan adalah korelasi product moment pearson dengan signifikaansi 5\%. Dengan demikian r-tabel sebesar 0,205. Pembuktian uji validitas dilakukan dengan membandingkan antara r-tabel dengan r-hitung yang dihasilkan. Itemitem pertanyaan dinyatakan valid apabila r-hitung lebuh besar daripada r-tabel. jika r-hitung lebih kecil daripada r-tabel maka item pertaanyaan 
dinyatakan tidak valid. Dari pengolahan data dan diperoleh hasil analisis yang disusun dalam tabel-tabel sebagai berikut :

1) Validitas Variabel Pelayanan

Tabel 4.3.1

Variabel Pelayanan

\begin{tabular}{|c|c|c|c|c|}
\hline No & $\begin{array}{c}\text { Item } \\
\text { pertanyaan }\end{array}$ & $\begin{array}{c}\text { Pearson } \\
\text { corelation }\end{array}$ & Sig. & Keterangan \\
\hline 1 & X.1.1 & 0.635 & 0.00 & Valid \\
\hline 2 & X.1.2 & 0.550 & 0.00 & Valid \\
\hline 3 & X.1.3 & 0.652 & 0.00 & Valid \\
\hline 4 & X.1.4 & 0.746 & 0.00 & Valid \\
\hline 5 & X.1.5 & 0.738 & 0.00 & Valid \\
\hline 6 & X.1.6 & 0.666 & 0.00 & Valid \\
\hline 7 & X.1.7 & 0.600 & 0.00 & Valid \\
\hline 8 & X.1.8 & 0.621 & 0.00 & Valid \\
\hline 9 & X.1.9 & 0.673 & 0.00 & Valid \\
\hline 10 & X.1.10 & 0.667 & 0.00 & Valid \\
\hline
\end{tabular}

Data Primer diolah, 2011

Berdasarkan hasil pengolahan data di atas, maka dapat dikemukakan bahwa hasil uji r-hitung pada setiap item pertanyaan variabel pelayanan lebih besar dari r-tabel. Dengan demikian semua item pertanyaan variabel pelayanan yang digunakan dalam kuesioner adalah valid.

2) Validitas Variabel Periklanan

Tabel 4.3.2

Variabel Periklanan

\begin{tabular}{|c|c|c|c|c|}
\hline No & $\begin{array}{c}\text { Item } \\
\text { pertanyaan }\end{array}$ & $\begin{array}{c}\text { Pearson } \\
\text { corelation }\end{array}$ & Sig. & Keterangan \\
\hline 1 & X.2.1 & 0.802 & 0.00 & Valid \\
\hline 2 & X.2.2 & 0.737 & 0.00 & Valid \\
\hline 3 & X.2.3 & 0.775 & 0.00 & Valid \\
\hline 4 & X.2.4 & 0.819 & 0.00 & Valid \\
\hline 5 & X.2.5 & 0.710 & 0.00 & Valid \\
\hline
\end{tabular}

Data Primer diolah, 2011 
Berdasarkan hasil pengolahan data di atas, maka dapat dikemukakan bahwa hasil uji r-hitung pada setiap item pertanyaan variabel periklanan lebih besar dari r-tabel. Dengan demikian semua item pertanyaan variabel periklanan yang digunakan dalam kuesioner adalah valid.

3) Validitas Variabel Keputusan

Tabel 4.3.3

Variabel Keputusan

\begin{tabular}{|c|c|r|r|r|}
\hline No & $\begin{array}{c}\text { Item } \\
\text { pertanyaan }\end{array}$ & $\begin{array}{c}\text { Pearson } \\
\text { corelation }\end{array}$ & Sig. & Keterangan \\
\hline 1 & Y.1 & 0.707 & 0.00 & Valid \\
\hline 2 & Y.2 & 0.704 & 0.00 & Valid \\
\hline 3 & Y.3 & 0.683 & 0.00 & Valid \\
\hline 4 & Y.4 & 0.631 & 0.00 & Valid \\
\hline 5 & Y.5 & 0.393 & 0.00 & Valid \\
\hline
\end{tabular}

Data Primer diolah, 2011

Berdasarkan hasil pengolahan data di atas, maka dapat dikemukakan bahwa hasil uji r-hitung pada setiap item pertanyaan variabel keputusan lebih besar dari r-tabel. Dengan demikian semua item pertanyaan variabel keputusan yang digunakan dalam kuesioner adalah valid.

\section{b. Realibilitas}

Uji reliabilitas dilakukan untuk mengetahui sejauh mana suatu hasil pengukuran relatif dapat dipercaya atau diandalkan. Tehnik yang digunakan adalah Cronbach alpha ${ }^{-} 0,60$ atau $6 \%$

Tabel 4.3.4

Data Reliabilitas

\begin{tabular}{|c|r|r|r|}
\hline Variabel & Nilai alpha & Nilai batas & Kesimpulan \\
\hline X.1 & 0.824 & 0.6 & Reliabel \\
X.2 & 0.839 & 0.6 & Reliabel \\
Y & 0.616 & 0.6 & Reliabel \\
\hline
\end{tabular}

Data Primer diolah, 2011 
Berdasarkan perhitungan yang dilakukan dengan bantuan SPSS, hasil uji reliabilitas terhadap variabel pelayanan adalah sebesar 0,824 , untuk variabel periklanan adalah sebesar 0,839 , untuk variabel keputusan adalah sebesar 0,616 . Dengan demikian semua item pertanyaan yang digunakan untuk mengukur variabel pelayanan, periklanan dan keputusan adalah reliabel sehingga semua item pertanyaan dapat digunakan sebagai alat pengukuran.

\section{Analisis Regresi Linier Berganda}

Berdasarkan hasil perhitungan kuantitatif dengan bantuan program SPSS dapat dilihat pada tabel berikut ini (data selengkapnya disajikan dalam lampiran):

Tabel 4.4.1

Hasil Analisis Regresi Linier Berganda

\begin{tabular}{|c|c|c|c|}
\hline \multirow{2}{*}{ No } & \multirow{2}{*}{ Variabel } & \multicolumn{2}{|c|}{ Unstandardized coefficient } \\
\cline { 3 - 4 } & & B & Std. Error \\
\hline 1 & Y & 6.807 & 1.648 \\
2 & X.1 & 0.090 & 0.046 \\
3 & X.2 & 0.422 & 0.080 \\
\hline
\end{tabular}

Data Primer diolah, 2011

Dari hasil analisis data maka selanjutnya dapat disusun persamaan regresi berganda sebagai berikut :

$\mathrm{Y}=6,807+0,090 \mathrm{X}_{1}+0,422 \mathrm{X}_{2}+\mathrm{e}$

Dari hasil persamaan regresi berganda di atas dapat diuraikan sebagai berikut :

1) Konstanta (a) bernilai positif Konstanta bernilai positif menunjukkan bahwa dalam keadaan tidak ada variabel $\mathrm{X}_{1}$ dan $\mathrm{X}_{2}$, maka keputusan menabung bernilai positif sebesar 6,807.

2) Koefisisen regresi variabel pelayanan $\left(b_{1}\right)$ bernilai positif Artinya apabila ada pengaruh dalam kualitas pelayanan $\left(\mathrm{X}_{1}\right)$, maka keputusan nasabah dalam menabung (Y) akan meningkat atau naik pula.

3) Koefisisen regresi variabel periklanan $\left(b_{2}\right)$ bernilai positif Artinya apabila ada pengaruh dari periklanan terhadap nasabah $\left(\mathrm{X}_{2}\right)$, maka keputusan nasabah dalam menabung (Y) akan meningkat atau naik pula. 


\section{Uji t (Uji Parsial)}

Tabel 4.5.1

Data Uji t

\begin{tabular}{|c|c|c|c|}
\hline Variabel & t hitung & t tabel & Kesimpulan \\
\hline X.1 & 1,948 & 1,658 & Signifikan \\
X.2 & 5,244 & 1,658 & Signifikan \\
\hline
\end{tabular}

Data Primer diolah, 2011

Uji t digunakan untuk mengetahui besarnya pengaruh masing-masing variabel independen terhadap variabel dependen secara individu.

Adapun langkah-langkah pengujiannya sebagai berikut:

1) Menentukan formulasi Ho dan $\mathrm{Ha}$

Ho : $\mathrm{bI}=0$ (tidak ada pengaruh yang signifikan variabel independen secara individu terhadap variabel dependen)

Ha : $\mathrm{bI} \neq 0$ (ada pengaruh yang signifikan variabel independen secara individu terhadap variabel dependen)

2) Menentukan tingkat signifikansi $\alpha=0,05$

$\mathrm{t}$ tabel $=\mathrm{t} \alpha / 2, \mathrm{n}-\mathrm{k}$

$\mathrm{n}=98$

$\mathrm{k}=2$

Diperoleh nilai t tabel $=1,658$

3) Kriteria pengujian

Ho diterima apabila $=-1,658 \leq \mathrm{t}$ hitung $\leq 1,658$

Ho diterima apabila $=\mathrm{t}$ hitung $\leq 1,658$ atau $\mathrm{t}$ hitung $\leq-1,658$

4) Perhitungan nilai $t$

Dari hasil perhitungan dengan bantuan program SPSS besarnya nilai thitung untuk masing-masing variabel independen adalah sebagai berikut:

a. Untuk variabel pelayanan besarnya t-hitung adalah 1,948

b. Untuk variabel periklanan besarnya t-hitung adalah 5,244 
5) Kesimpulan

a. Untuk variabel pelayanan didapat nilai t-hitung sebesar 1,948 yang lebih besar dari t-tabel sebesar 1,658. Dari hasil tersebut dapat disimpulkan bahwa Ho ditolak dan Ha diterima yang artinya terdapat pengaruh yang signifikan antara variabel pelayanan terhadap keputusan nasabah dalam menabung. Dari hasil analisis tersebut dapat diketahui bahwa hipotesis variabel pelayanan yang terdiri dari dimensi tangible (bukti fisik), reliability (keandalan), responsiveness (daya tanggap), assurance (jaminan), dan emphaty (empati) masing-masing berpengaruh secara signifikan terhadap variabel keputusan menabung. Dengan demikian dapat berarti bahwa hipotesis H1 "Ada pengaruh yang signifikan antara kualitas pelayanan dengan keputusan nasabah menabung" diterima.

b. Untuk variabel periklanan didapat nilai t-hitung sebesar 5,244 yang lebih besar dari t-tabel sebesar 1,658. Dari hasil tersebut dapat disimpulkan bahwa Ho ditolak dan Ha diterima yang artinya terdapat pengaruh yang signifikan antara variabel periklanan terhadap keputusan menabung. Dari hasil analisis tersebut dapat diketahui bahwa variabel periklanan yang terdiri dari unsur-unsur kejelasan informasi dari penyampaian iklan, kepercayaan dari iklan, iklan yang mudah diikuti, iklan yang menarik dan iklan yang dirancang dengan baik, masingmasing berpengaruh secara signifikan terhadap variabel keputusan nasabah dalam menabung. Dengan demikian dapat berarti bahwa hipotesis H2 "Ada pengaruh yang signifikan antara periklanan dengan keputusan nasabah menabung" diterima.

\section{Uji F}

Tabel 4.6.1

Data Uji F

\begin{tabular}{|c|c|c|c|c|c|}
\hline Model & $\begin{array}{l}\text { Sum of } \\
\text { Squares }\end{array}$ & Df & $\begin{array}{c}\text { Mean } \\
\text { Square }\end{array}$ & $\mathbf{F}$ & Sig. \\
\hline 1 Regression & 154.742 & 2 & 77.371 & 29.629 & $0.000^{\mathrm{a}}$ \\
\hline Residual & 248.074 & 95 & 2.811 & & \\
\hline Total & 402.816 & 97 & & & \\
\hline
\end{tabular}

Data Primer diolah, 2011 
Uji F merupakan pengujian secara serempak untuk mengetahui pengaruh faktor kualitas pelayanan dan periklanan secara bersama-sama terhadap keputusan menabung. Adapun perhitungannya adalah sebagai berikut:

1) Menyusun formulasi Ho dan $\mathrm{Ha}$

Ho : b1, b2, b3 = 0 (tidak ada pengaruh antara pelayanan dan periklanan)

$\mathrm{Ha}: \mathrm{b} 1, \mathrm{~b} 2, \mathrm{~b} 3 \neq 0$ (ada pengaruh antara pelayanan dan periklanan)

2) Menentukan tingkat signifikansi $\alpha=0,05$

$\mathrm{F}$ tabel $=\mathrm{F} \alpha, \mathrm{k}, \mathrm{n}-\mathrm{k}-1$

$\mathrm{n}=98$

$\mathrm{k}=2$

Diperoleh nilai $\mathrm{F}$ tabel $=3,09$

3) Kriteria pengujian

Ho diterima apabila: $\mathrm{F}$ hitung $\leq \mathrm{F}$ tabel

Ho tidak diterima apabila: $\mathrm{F}$ hitung $>\mathrm{F}$ tabel

4) Perhitungan nilai $F$

Dari hasil perhitungan dengan bantuan program SPSS diketahui bahwa nilai $\mathrm{F}$ hitung 29,68

5) Kesimpulan

Berdasarkan hasil tersebut dapat diketahui bahwa nilai $\mathrm{F}$ hitung sebesar 29,68 yang lebih besar dari F tabel sebesar 3,09. Dari hasil tersebut dapat disimpulkan bahwa Ho ditolak dan Ha diterima yang artinya terdapat pengaruh yang signifikan secara bersama-sama antara variabel kualitas pelayanan dan periklanan terhadap variabel keputusan menabung. Dengan demikian dapat berarti bahwa hipotesis H3 "Ada pengaruh yang signifikan secara bersama-sama antara kualitas pelayanan dan periklanan dengan keputusan nasabah menabung" diterima.

\section{Uji Determinan $\mathbf{R}^{2}$}

Koefisien determinasi merupakan besaran yang menunjukkan besarnya variasi variabel dependen yang dapat dijelaskan oleh variable independennya. Dengan kata lain, koefisien determinasi ini digunakan untuk 
mengukur seberapa jauh variabel-variabel bebas dalam menerangkan variabel terikatnya. Nilai koefisien determinasi ditentukan dengan nilai adjusted $R$ square sebagaimana dapat dilihat pada tabel :

Tabel 4.7.1

Data Uji $\mathrm{R}^{2}$

\begin{tabular}{|c|c|c|c|c|}
\hline Model & $\mathrm{R}$ & $\mathrm{R}$ Square & $\begin{array}{c}\text { Adjusted } \\
\text { R Square }\end{array}$ & $\begin{array}{c}\text { Std. Error of } \\
\text { the Estimate }\end{array}$ \\
\hline 1 & 0,620 & 0,384 & 0,371 & 1,616 \\
\hline
\end{tabular}

Data Primer diolah, 2011

Hasil perhitungan regresi dapat diketahui bahwa koefisien determinas (adjusted $R^{2}$ ) yang diperoleh sebesar 0,384 . Hal ini berarti $38,4 \%$ variabel keputusan menabung dapat dijelaskan oleh variabel kulaitas pelayanan dan periklanan, sedangkan sisanya sebesar $61,6 \%$ diterangkan oleh variabel lain yang tidak diajukan dalam penelitian ini.

\section{Uji Asumsi klasik}

\section{a) Uji normalitas}

Uji normalitas bertujuan untuk menguji apakah dalam model regresi, variabel bebas dan variabel terikat, keduanya terdistribusikan secara normal ataukah tidak.

Normalitas data dalam penelitian dilihat dengan cara memperhatikan titik-titik pada Normal P-Plot of Regression Standardized Residual dari variabel terikat. Persyaratan dari uji normalitas adalah jika data menyebar di sekitar garis diagonal dan mengikuti arah garis diagonal, maka model regresi memenuhi asumsi normalitas. Jika data menyebar jauh dari garis diagonal dan/atau tidak mengikuti garis diagonal, maka model regresi tidak memenuhi asumsi normalitas. 
Gambar 4.8.1

\section{Normal P-P Plot of Regression Standardized Residual}

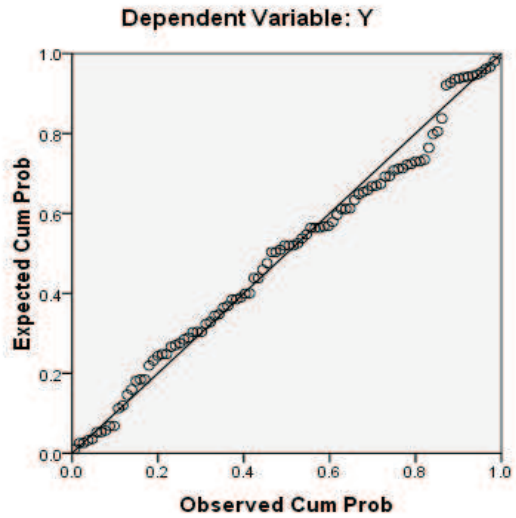

Data Primer diolah, 2011

Dari gambar tersebut didapatkan hasil bahwa semua data berdistribusi secara normal, sebaran data berada disekitar garis diagonal.

\section{b) Uji Multikolinearitas}

Pengujian multikolinieritas bertujuan untuk mengetahui hubungan yang sempurna antar variabel bebas dalam model regresi. Gejala multikolinieritas dapat dilihat dari nilai tolerance dan nilai Varian Inflation Factor (VIF). Bila nilai VIF lebih kecil dari 10 dan nilai toleransinya di atas 0,1 atau $10 \%$ maka dapat disimpulkan bahwa model regresi tersebut tidak terjadi multikolinieritas (Ghozali, 2005).

Tabel 4.8.1

Data Uji Multikolonieritas

\begin{tabular}{|c|c|c|c|}
\hline Variabel & Tolerance & VIF & Keterangan \\
\hline $\mathrm{X} 1$ & 0,713 & 1,403 & Tidak ada multikolinearitas \\
$\mathrm{X} 2$ & 0,713 & 1,403 & Tidak ada multikolinearitas \\
\hline
\end{tabular}

Data Primer diolah, 2011

Dari tabel tersebut menunjukkan bahwa nilai VIF semua variabel bebas dalam penelitian ini lebih kecil dari 10 sedangkan nilai toleransi semua 
variabel bebas lebih dari $10 \%$ yang berarti tidak terjadi korelasi antar variabel bebas yang nilainya lebih dari $90 \%$, dengan demikian dapat disimpulkan bahwa tidak terdapat gejala multikolinieritas antar variabel bebas dalam model regresi.

\section{c) Uji Heterokedastisitas}

Uji ini bertujuan untuk menguji apakah dalam sebuah model regresi terjadi ketidaksamaan varians dari residual, dari satu pengamatan ke pengamatan yang lain.

Jika varians dari residual dari satu pengamatan ke pengamatan yang lain tetap, maka disebut homoskedastisitas dan jika varians berbeda, disebut heterokedastisitas. Model regresi yang baik adalah tidak terjadi heterokedastisitas. Untuk mendeteksi ada tidaknya heterokedastisitas dapat digunakan metode grafik Scatterplot yang dihasilkan dari output program SPSS versi 16, Apabila pada gambar menunjukkan bahwa titiktitik menyebar secara acak serta tersebar baik di atas maupun di bawah angka 0 pada sumbu Y, maka hal ini dapat disimpulkan tidak terjadi adanya heterokedastisitas pada model regresi (Ghozali, 2005).

Gambar 4.8.2

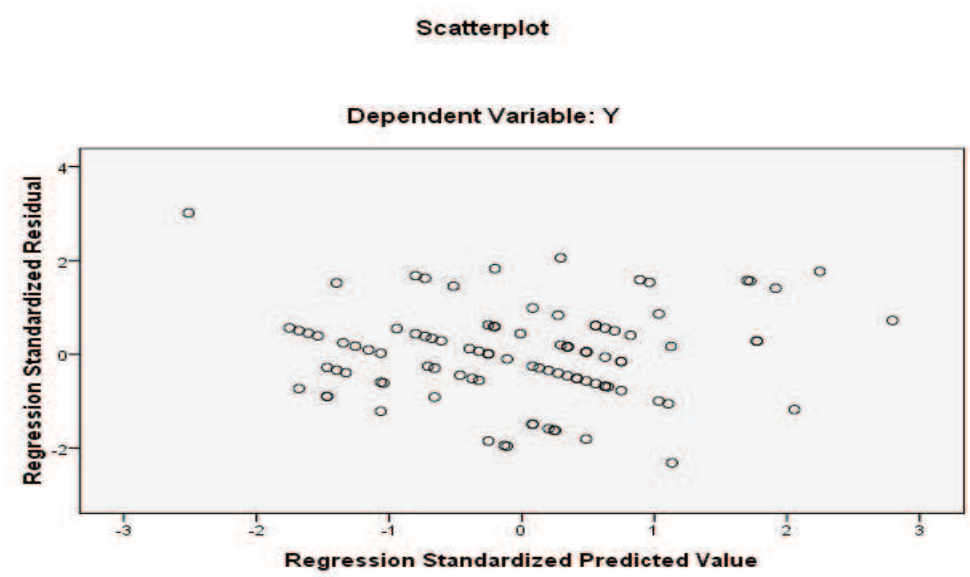

Data Primer diolah, 2011

Dari grafik tersebut terlihat titik-titik yang menyebar secara acak, tidak membentuk suatu pola tertentu yang jelas, serta tersebar baik di atas 
maupun di bawah angka 0 (nol) pada sumbu $\mathrm{Y}$, hal ini berarti tidak terjadi penyimpangan asumsi klasik heterokedastisitas pada model regresi yang dibuat, dengan kata lain menerima hipotesis homoskedastisitas.

\section{Kesimpulan}

Berdasarkan hasil pengujian secara statistik dapat terlihat dengan jelas bahwa secara parsial (individu) semua variabel bebas berpengaruh terhadap variabel terikat. Pengaruh yang diberikan kedua variabel bebas tersebut bersifat positif artinya semakin tinggi pelayanan dan periklanan maka mengakibatkan semakin tinggi pula keputusan nasabah dalam menabung pada BTN Syariah Surakarta. Hasil tersebut sesuai dengan hipotesis yang diajukan. Hasil penelitian ini juga sesuai dengan hasil penelitian sebelumnya. Penjelasan dari masing-masing pengaruh variabel dijelaskan sebagai berikut:

1. Pengaruh Kualitas Pelayanan Terhadap Keputusan Menabung Hasil pengujian hipotesis (H1) telah membuktikan terdapat pengaruh antara kualitas pelayanan terhadap keputusan menabung. Melalui hasil perhitungan yang telah dilakukan diperoleh nilai t hitung sebesar 1,948 dengan taraf signifikansi hasil sebesar 0,000 tersebut lebih kecil dari 0,05, dengan demikian Ha diterima dan Ho ditolak. Pengujian ini secara statistik membuktikan bahwa kualitas pelayanan berpengaruh positif terhadap keputusan menabung. Artinya bahwa ada pengaruh antara variabel kualitas pelayanan terhadap keputusan nasabah dalam menabung pada BTN Syariah Surakarta.

2. Pengaruh Periklanan terhadap Keputusan Menabung

Hasil pengujian hipotesis (H2) telah membuktikan terdapat pengaruh antara periklanan terhadap keputusan menabung. Melalui hasil perhitungan yang telah dilakukan diperoleh nilai t hitung sebesar 5,244 dengan taraf signifikansi hasil sebesar 0,000 tersebut lebih kecil dari 0,05 , yang berarti bahwa hipotesis dalam penelitian ini menerima $\mathrm{Ha}$ dan menolak Ho. Pengujian ini secara statistik membuktikan bahwa periklanan berpengaruh terhadap keputusan menabung. Artinya bahwa ada pengaruh antara variabel periklanan terhadap keputusan menabung nasabah dalam BTN Syariah Surakarta. 
3. Pengaruh Kualitas Pelayanan dan Periklanan terhadap Keputusan Menabung

Hasil pengujian hipotesis (H3) telah membuktikan terdapat pengaruh antara kualitas pelayanan dan periklanan terhadap keputusan menabung. Melalui hasil perhitungan yang telah dilakukan diperoleh nilai $\mathrm{F}$ hitung sebesar 29,68 lebih besar dari F tabel sebesar 3,09 yang berarti bahwa hipotesis dalam penelitian ini menerima Ha dan menolak Ho. Pengujian ini secara statistik membuktikan bahwa secara bersama-sama kualitas pelayanan dan periklanan berpengaruh signifikan terhadap keputusan menabung.

\section{DAFTAR PUSTAKA}

Baria'ah, et.al., 2009. Hubungan Antara Kualitas Layanan Bank dengan Minat Menabung pada PT. BRI Kantor Cabang Ungaran, Semarang: UNDIP.

Ghozali, Imam, 2005. Aplikasi Analisis Multivariate dengan Program SPSS, Semarang: Badan Penertbit UNDIP.

Kotler, Philips, 2001. Manajemen Pemasaran: Analisis, Perencanaan dan Implementasi Dan Kontrol, Jakarta: Erlangga.

Statistik BI, 2011, www.bi.go.id.

Swastha, Basu dan Irawan, 2003. Manajemen pemasaran Modern, Yogyakarta: Liberty.

Tjiptono, Fandy. 2001. Manajemen Jasa, Yogyakarta: Andi Offset.

Umar, Husein. 2001. Metodologi Penelitian Aplikasi dalam Pemasaran, Jakarta: PT. Gramedia Pustaka Utama.

Wahjono, 2010. Manajemen Pemasaran Bank, Yogyakarta: Graha Ilmu 